\title{
The Vegetation of Lakes and Swamps in Japan.
}

\author{
by
}

H. Nakano.

I. Teganuma (Tega-Swamp).

\section{INTRODUCTION.}

Many investigations in the plant distribution of lakes and swamps in Europe and North America reveal us that there always occur plant associations arranged in zones. We owe the researches upon these zones in Europe to Magnin, ${ }^{1)}$ SchröTER, ${ }^{2)}$ BRAND, ${ }^{3)} \mathrm{Y}_{\mathrm{APP}}{ }^{4)} \& \mathrm{c}$, and those in the United States of America to Coul,es, ${ }^{5)}$ Reed, ${ }^{6)}$ Transeaul ${ }^{7)}$ and others.

In Japan, such an exploring has never been undertaken till present. So I made an attempt to find out what a zonal arrangement exists in Japanese lakes and swamps, and to investigate what ecological factors have influenced the arrangement.

We have many large reed-swamps (after WARMING's classification of swamps ${ }^{8)}$ ) in Japan, as Kasumigaura, Kitaura, Inbanuma, Ushikunuma, Teganuma and others. For several years I have been studying especially the plant formation of Teganuma, and have distinguished five zones in it. The origin and explanation of this plant formation are the chief object of the present report.

1) and 2) cited from Warming's Oecology of plants, 1909, p. 188.

As to the zonal arrangemert of plant associations of lakes, we may refer also Schimper's Pflanzen-Geographie, 1908, p. 850.

3) Bot. Centralb. Bd. 65, 1895. p. 1-13.

4) New phytologist, 1908, p. 69.

5) B t. Gaz. Vol. 31, 1901. p. 145.

6) Ditto, Vol. 34. 1902. p. 129

7) Ditto, Vol. 36. 1904 p. 403.

8) Warming's "Reed Swamps" may contain lakes and swamps in a limnological sense. 
Teganuma lies about 30 miles to the northeast of Tokyo, and is situated in the northern part of the Chiba prefecture. Its longer axis is nearly parallel to the River Tone to which the swamp is connected by an aqueduct in its eastern part to drain the swamp into the river and to prevent the inflowing of the river into the swamp.

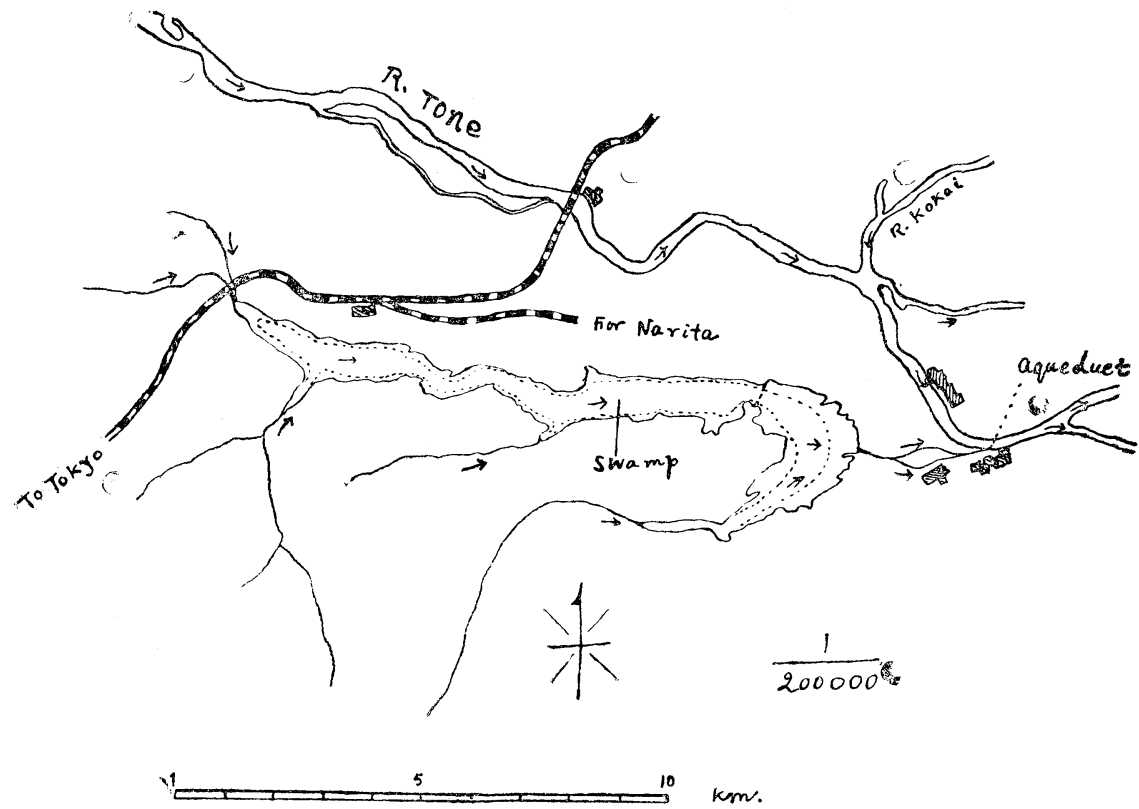

F ig. 1.

Tega-Swamp and its vicinity. littoral flora.

The swamp is about $12 \mathrm{~km}$ in length, and runs from east to west, and is about $0.65 \mathrm{~km}$ in breadth. It bends southward and widens in its eastern end, being about $2.3 \mathrm{~km}$ from north to south and about $1.3 \mathrm{~km}$ from east to west.

Five principal brooks flow into the swamp. Two of them that flow into the swamp at its northwestern corner come from the neighbourhoods of the villages Judayu and Shorenji. Another brook on the southwestern side is a little larger than 
the former two, and originates at the village Awano. Another one is the smallest, and is on the sonthern side of the swamp. The rest on the southwestern side is the largest of the five and is called by the name of "Kanayamaotoshi," which name signifies that it starts near the village Kanayama.

These five brooks have usually very spare water, but during the rainy season, they bring to the swamp a large amount of water. Then the swamp swells rapidly, and often flows over the banks into the surrounding fields.

Besides these brooks, the underground water also feeds the swamp, because the swamp basin and surrounding valley are about $10-12 \mathrm{~m}$ below the top of surrounding hills, and the level of the underground water lies about $10 \mathrm{~m}$ down from the surface of the hills, so that the level of the underground-water situates a little higher than the level of the valley. For this reason, in the valley of the swamp, a boring can make a flowing well.

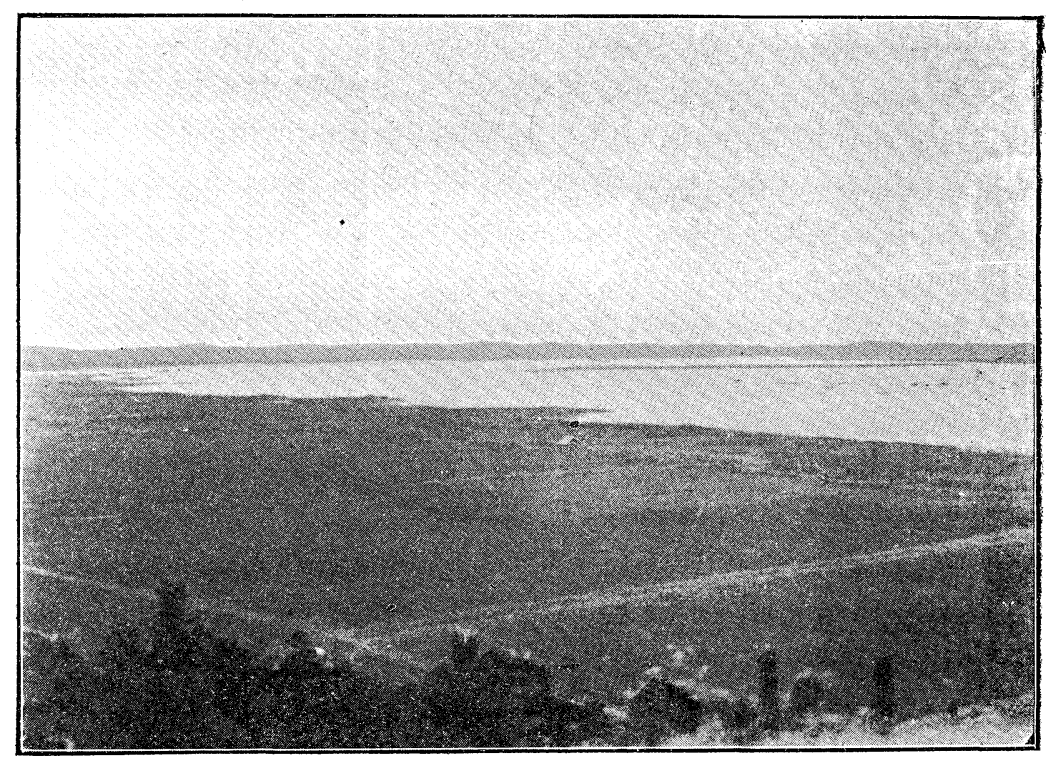

Fig. 2.

Landscape of J'ega-Swamp, showing its surrounding hills and rice fields. (zone of Sagittılia sagittifclia). 
The "Kama" (or literally kettle), which name is given to the spring at the bottom of the swamp, is no other than the spring of the underground water.

The depth of the swamp is uniform and its study is of a little interest. The central part which is inhabited by the submerged plants is about $2 \mathrm{~m}$ deep in a ordinary state but in high water (in early summer and autumn) it becomes often $3.5 \mathrm{~m}$ deep, and in low water (in mid summer) often $1.7 \mathrm{~m}$. The littoral part shallower than $2 \mathrm{~m}$ is the habitat of swimming hydrophytes and helophytes. This fact comes necessarily from the origin of the swamp, upon which I shall return in later pages.

The surrounding hills clad with conifers (Pinus Thumbergii, $P$. densiflora, Cryptomeria japonica, \&c) are composed of a few sandy layers covered by a layer of loam. The latter layers imply (especially in the villages Fuze and Kamenari) the fossils of Mollusca and Echinodermata, which belong according Dr. Tokunaga ${ }^{1)}$ and others, ${ }^{2)}$ to the diluvial epoch. I have there collected 28 species of fossils.

Beneath these sandy layers comes a compact layer of clay and sand. The underground water flows probably over this compact layer. At the bottom of the swamp we find a humus soil black-brownish in colour and sulphur-like in smell. This soil ${ }^{3)}$ contains a large quantity of the relics of diatoms, and often is interwoven with plant textures and shows a neutral reaction. The swamp is a very fitted abode for fishes, as eels, wels, carps, pond smelt and etc. The water is not fresh and has an unpleasant smell; It is so very clear in a calm day, that we can see the beautiful foliage of submerged plants at $1 \mathrm{~m}$ down from the surface of the water, but on a windy day it soon becomes brownish, because the waves disturb the muddy shore and bottom.

1) Tokunaga: Fossils from the environs of Tokio, Jour. Sci. Coll. Imp. Univ. Tokyo. Vol. 21. Art 2.

2) The Journal of the geological society of Tokyo, Vol. 11. p. 491 (Japanese)

3) Compare, Warming l.c. p. 6?. "Ordinary humus." also, Schimper 1.c. p. 118-120. "Der milde Humus." 
In the following lines I shall try to give a brief account about the origin of the swamp. For this evidence we may point out the following facts :-

a). The swamp has the form of a very long crescent, its axis running parallel to the course of the Tone, and its depth being rather uniform.

b). The eastern part is still connected with the river, and it may be well conjectured by the observations of the topography in this district, that in old ages, the western valley of the swamp was connected with that of the river.

From these it is sufficient for us to imagine that the valley of the swamp is the cutt-off part of the meandering course of the river. Besides these we may enumerate another evidence of the river-origin of the swamp.

The place near the swamp and its vicinity suffer an inundation every year, since the River "Kinu" which collects the water of the mountaineous districts of Nikko flows into the Tone at a point about five miles west apart from the swamp. When heavy rain in summer last for many days the Tone rises and flows over cultured fields. So even in the present day, change of the river course is likely to occur when it is not prevented by artificial works.

Also we find many river-relic-swamps of a smaller scale in the bank of the river, for example, in a pool between the village "Nakabyo" and islet "Chobetsu." The western part of the pool was buried by a sandy deposit while the eastern part still connects with the river through a small brooklet.

From an old record ${ }^{1)}$ we know that in old times the River Kinu combined with the River Kokai flowed into the River Tone. It may, therefore, be well inferred that in former ages, the current of the Tone along this district was stronger than in the present.

Taking all the above cases into consideration, it may not be too bold to conclude that the Tega-swamp was formed through the change of the course of the Tone.

1) Sotan Akamatsu: Pictorial records of the River Tone. 
II. Plant Associations.

Round the central association of submerged plants (Potamogeton), there occur four concentric zones of marsh plants in the basin of the swamp. Now I will give an account of the distinctions of these five zones.

1. Zone of Potamogeton.

This zone extends through all the central part of the swamp of the depth of $1.6-2 \mathrm{~m}$. Owing to strong winds and waves which prevail in this zone of the swamp swimming hydrophytes can not develop well, and helophytes also can not proceed into such a deep basin. Being favorable to epharmony, ${ }^{1)}$ the submerged plants among which Potamogeton prevails, well flourish in this zone as the competitor of all, in such a large quantity that they often check the boating. This zone proceeds further landward through brooks and brooklets. As the plants of this zone we count the following :-

Chara sp., Nittlla sp., *Vallisneria spiralis L., * Potamogeton Gaudichaudi Chaм., * P. polygonifolius Pour., * P. natans L., *P. lucens L. var. teganumensis Makino., *P. crispus L., *P. perfoliatus L., P. serrulatus Reg. et MaAck., *P. Miduhikimo Makino, *Myriophyllum spicatum L., *Hydrilla verticillata Royle var. Roxburgii Casp., Ceratophyllum demersum L., Najas major ALL., $N$. minor AlL., N. graminea DEL.

The plants marked with an asterix are found abundantly and used by farmers as a manure for their fields. Here it is a noticeable fact that deep submerged leaves of Potamogeton natans and $P$. lucens var. teganumensis are linear while upper leaves are lanceolate.

2. Zone of Zizania aquatica L.

This zone proceeds as the innermost association of the littoral flora and occupies the place of about $1.7 \mathrm{~m}$ deep in average. In this zone the conditions (as to wave and depth) of vegetation are not sufficient to give a more favorable place for swimming hydrophytes and helophytes, so that they can not flourish so

1) WARMing, 1. c. p. 2.

2) The Bot. Magaz. Tukyo, Vol. XIX p. 142. 
well as in the next zone. Among a loose association of Zizania aquatica, it is very sparsely found Limnanthemum indicum Griseb. Here occur also many species of the preceding zone and especially such as Ceratophyllum demersum, and Najas minor.

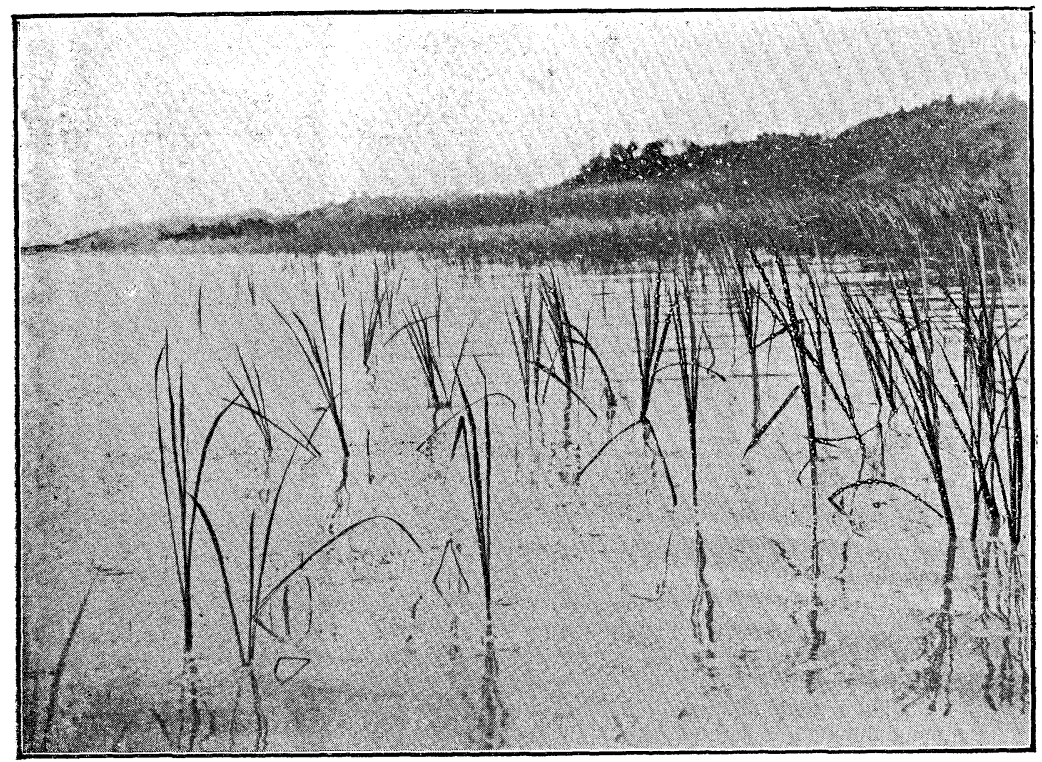

Fig. 3.

Zone of Zizania aquatica.

Swimming hydrophyte (Limnanthemum indicum) among Zizania aquatica; landward follows directly Phragmites-zone, owing to the absence of Typha-zore.

3. Zone of Typha angustifolia.

This zone comes immediately outside the preceding zone. The depth here measures about $1 \mathrm{~m}$ in average. The favorable movement and depth, of water has evoked the dense growth of Zizania aquatica, and consequently has given a happy residence jor Typha angustifolia Bory et Снамв., Scirpus Tabernæmontani Gmel., and for many swimming hydrophytes. Among the latter the most luxuriant plants are:-Nymphæa tetragona Georg. var. angustata CASP., Limnanthemum indicum Griseb. 
Associated with these, there are:-Limnanthemum nymphoides Link. var. japonica MiQ., Hydrillaa siatica MiQ., Utricularia vulgaris L., Trapella sinensis Or.v., and the same submerged hydrophytes as in the preceding zone.

A remarkable fact in this zone is that the large patches (1-2m in diameter) of Zizania aquatica are floating freely, which country men call "Ukishima" (=floating islets).

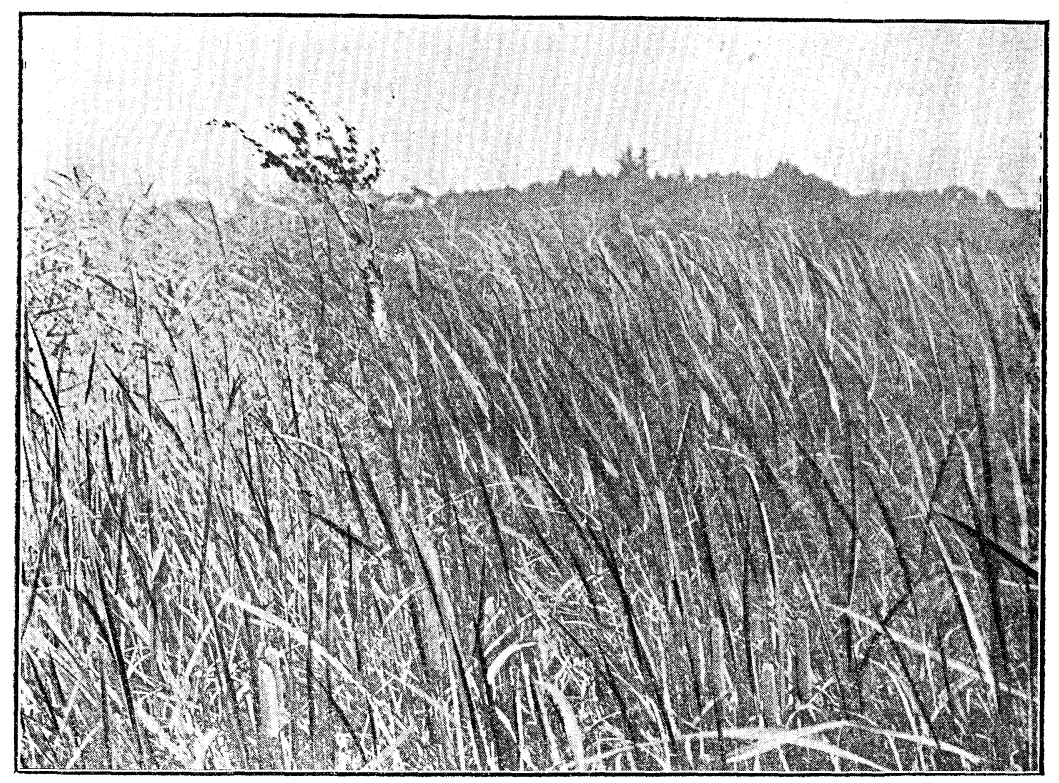

Fig. 4.

Laxuriant growth of Typha anyustifolia among the dense growth of Zizama aqualica.

(In the forogronnd we see the characteristic flowers of Tipha.)

On account of a tangled growth of marsh plants it is very hard for boating through this zone. In this zone the movement of water is very feeble so that oxidation of plant relics can not go on sufficiently ${ }^{1)}$ and produces gases of a very unpleasant smell. Thus a deep accumulation of humus soil is produced at its bottom. I should think that a luxuriant vegetation of

1) WARMing 1.c. p. 63. 
Nymphæa, Brasenia, Euryale etc., mostly depends upon the deposit of humus soil.

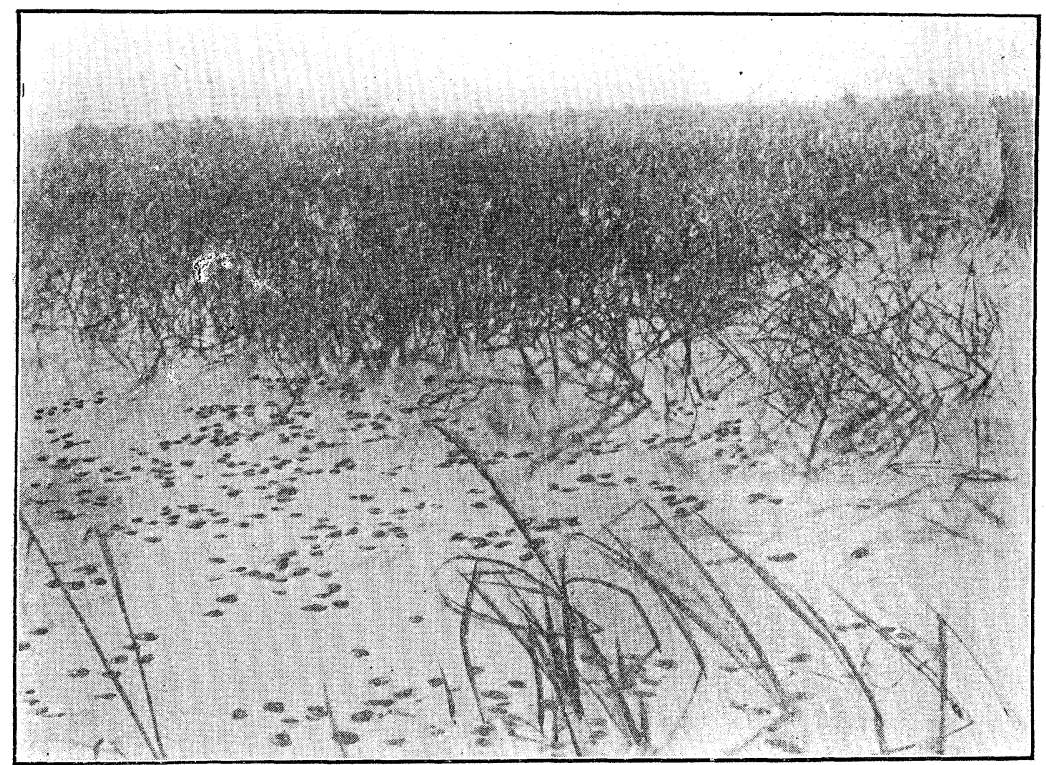

F g. 5.

Zne of Tipla args'ifolia in the eastern part of the swamp; Brasenia peltata among the growth of Zisania; in the back-ground we see the vegetation level2) of Lizinia aqualica.

This zone is wanting where the littoral part of the swamp is narrow and the human agency to reclaim the swamp in order to make rice-fields is strongly displayed. But the zone is the widest in the eastern end of the swamp, and the plants, as Brasenia peltata Pursh., Euryale ferox Salisb. and Trapa bispinosa Rox., ${ }^{1)}$ are found abundantly, while they

1) Of this species I have found three types:-

$\alpha$. Type which resembles the Roxburghian type.

$\beta$. Type which is different from $\alpha$, in having red characteristic spots on the leaves and also in the characterist $c$ fruits etc.

$\gamma$. Type which is different from $\alpha$ and $\beta$, in having a discontinuous disk at the base of sepals, and also in the characteristic fruits etc.

I shall give accounts on these points more precisely in another paper in near future.

2) YAPP: On strafication in the vegetation of a marsh etc. Annals of Botany Vol. 23, April 1909. 
are not found at other places on account of various causes which will be explained later. On the contrary, Typha angustifolia occurs as a characteristic plant everywhere in this zone.

4. Zone of Phragmites communis Trin.

This zone follows indistinctly outside the foregoing, but Typha and Zizania diminish gradually landward and at last give way to a large pure association of Phragmites communis on the shore. When deep humus soil occurs here, it is intermingled with the swimming plants as Limnanthemum nymphoides var. japonica, Hydrilla asiatica, and especially Nymphæa tetragona var. angustata. On the bank it is mixed with Salix purpurea L. and S. nipponica FR. et SAv.

The three last zones of marsh plants (helophytes) extend from the depth of about $1.7 \mathrm{~m}$ to the shore averaging the width

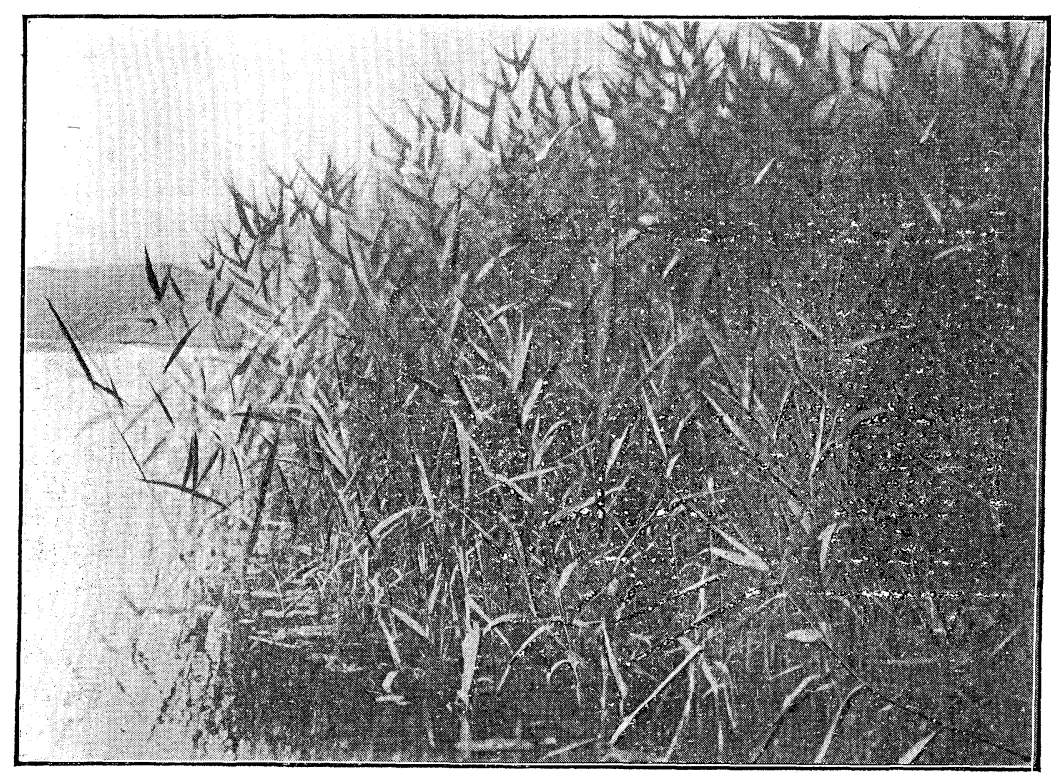

Fig. 6.

$Z$,ne of Phragmites communis, associated with the luxuriant vegetation of Nymphcea tetragona var. angustata. 
of about $100 \mathrm{~m}$. The width increases often to five times in the eastern part of the swamp, but it becomes sometime very narrow by artificial works.

\section{Zone of Sagittaria sagittifolia.}

The zone is met with in the shallow pools, brooklets, and the rice fields in the surrounding of the swamp. We may point out the following plants as the inhabitants of this zone :-

Blyxa caulescens Max., Ottelia alismoides Perb., Sagittalia sagittifolia L., Alisma plantago L. var. angustifolium Kunth, Caldesia parnassifolia PArL., Sagittalia pygmæa Mro., Glyceria acutiflora ToR., Leersia hexandra Sw., Eleocharis plantaginea R. BR., Scirpus mucronatus L., Sc. triqueter L., Sc. lineolatus F. S. Acorus calamus L., Eriocaulon sieboldianum Steud., Aneilema Keisak Hassk., Juncus prismatocarpus var. Leschenaulti F. Buch., Subvar. pluritubulosus PresL., Monochoria korsakowii Reg. et MAACK., $M$. vaginalis Pr. var. plantaginea Solms.-Laub., Polygonum hydropiper L. var. vulgare Meisn., Ranunculus sceleratus L., Rotala mexicana $\mathrm{CH}_{\text {., }}$ Myriophyllum ussuriense Max., Nuphar japonica D.C., Oenanthe stolonifera D.C., Ambulia sessiflora Kосн., Marsilia quadrifoliata L.

Besides these, we find here floating plants as :-

Azolla pinnata R. BR. var. Africana BAK., Salvinia natans Hoff., Lemna major GrIFF., Lemna paucicostata HLGel.

Here also occurs the vigorous growth of Potamogeton polygonifolius. Of these plants, the peculiar aspect of the vegetion of Sagittaria sagittifolia attracts our attention most remarkably, hence the zone is so named.

Now I will explain the inhabitats of five zones with schematical figures. As a representative of each zone let us take a characteristic plant. The number of individuals is represented with dots. 


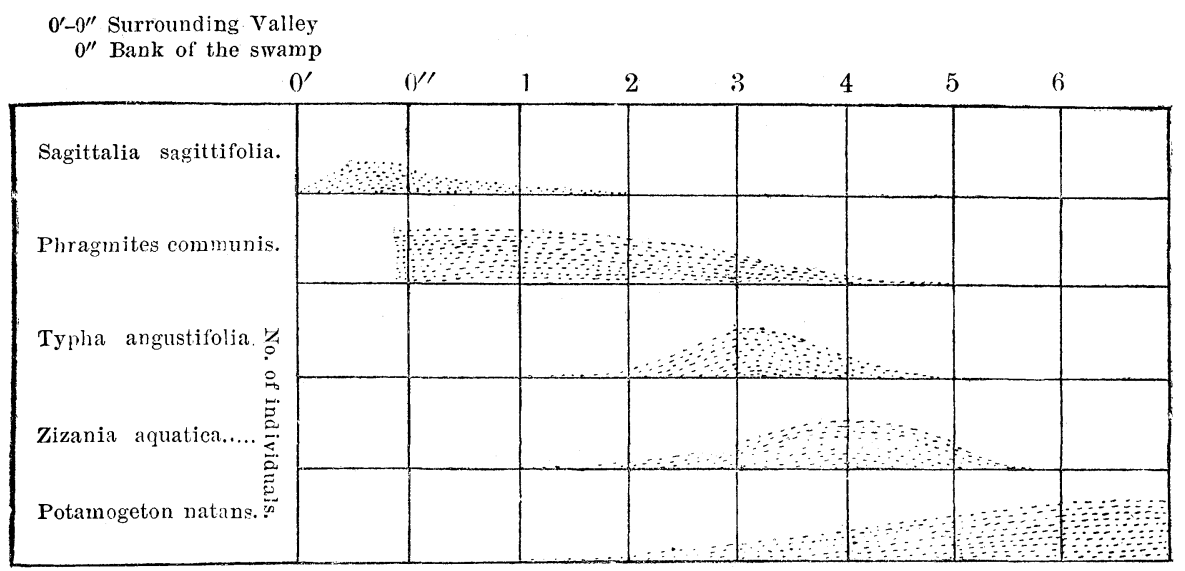

Depth in Shaku (ca. ft.)

These figures are obtained from the survey of the typical vegetations of the swamp, as in Kōnoyama, Nenogami, Minowa, etc.

\section{Ecological Factors.}

Upon considering all the facts above mentioned, we may point out at least the following agencies as the ecological factors here at work.

a. bathometric factor

b. hydrodynamic factor

c. edaphic factor

d. human interference

a. Bathometric factor.

The association of Zizania aquatica proceeds in the swamp as the innermost pioneer of the littoral flora, while Phragmites always comes on the shore, and Typha with a dense growth of Zizania occurs between them. On the contrary, the central part of the swamp is a mere abode of submerged plants. In this case, the supply of the water to the plant and the regulation of transpiration, as WARMING referred, ${ }^{1)}$ seem directly to evoke the arrangement of five zones, according to the rate of adaptation to water. Therefore, the distinction of four zones, Potamogeton-, Zizania-, Typha- and Phragmites-zone would have probably come indirectly from the difference of the

1) l. c. p. 96 . 
depth of water. In the eastern part of the swamp, an immensly wide area is shallow and affords a very profitable residense to the littoral flora. Also in the inlets of the swamp, which are tusually very calm and shallow, there occurs the vigorous vegetation of marsh plants. Indeed, in the shallow parts of the swamp, there always occur Zizania-and Phragmites-zone even in the midst of the swamp; for example, along the "Sengen" embankment which proceeds to the midst of the swamp.

b. Hydrodynamic factor.

Submerged hydrophytes can live in open water, while swimming hydrophytes always find their favorable residence among Zizania-, Typha-, and Phragmites- zone, which all give them a shelter against strong winds and waves.

It is said that the extinction of three species, Brasenia peltata, Euryale ferox and Trapa bispinosa in the Typha- zone of the middle and western portions of the swamp occurred during the flood in 1882 when the flow of the Tone flooded over the swamp from its eastern valley. This may be true, because it can be accepted that these three plants in the eastern part of the swamp, on account of its wide area, survived a little, while these of the corresponding zones in other places were wholly destroyed. We may here imagine that the violent obstructions of their respiration and assimilation, caused by high water and muddy particles, was a main cause of their extinction. Here, we shall not also forget to consider the mechanical disturbance of the flood.

\section{Edaphic factor.}

REED) found in one of "Sister lakes" that humus soil is very favorable for Typha, Nymphæa and Carex, and calcareous soil for Chara, Potamogeton, Scirpus lacustris \&c. WARMing ${ }^{2)}$ also suggests that the former is particularly associated with nymphaceous vegetation. My observation agrees with theirs, because Nymphaea tetragona, var. angustata is accompanied

1) 1. c. p. 135 .

2) 1.c. p. 65 . 
always by a dense association of Zizania (t. i. in Typha-zone) and Phragmites, where a deep layer of humus soil is deposited. On the contrary, when Phragmites and Zizania associations grow on the sandy basin, they have no Nymphæa-association among them.

Brand ${ }^{1)}$ states in his ecological study of "Wuirmsee" that Scirpus lacustris can grow on a hard ground, so that it comes lakeward, while Phragmites communis comes landward, because it needs a shrammy habitat. This explanation does not seem to hold good in the swamp, for here the situation of Scirpus lacustris L. var. Tabernæmontani GMeL (=Sc. Tabernæmontani Prant.) is so muddy as in the Phragmites-zone, and indeed Phragmites often can make a large association even on a sandy basin. I think, therefore, that the difference of their habitats was caused by that of their adaptation to water.

That large associations of Brasenia peltata, Euryale ferox, and Trapa bispinosa are found only in the eastern part of the swamp, seems to be remarkably correlated with the deposit of humus soil, which occurs most richly in that part of the swamp. It is said that they had been poor in the western portions of the swamp even in old times, where they were destroyed by the flood of 1882. Accordingly, and especially by the abundance of other helophytes, the vegetation of the eastern part of the swamp is generally rich and luxuriant.

d. Human interference.

This factor may be considered as another cause of the extinction of Brasenia peltata, Euryale ferox and Trapa bispinosa in the middle and western portions of the swamp.

In this swamp, landmen endeavour to reclaim the shore to extend their rice-fields. Then they collect the humus soil as manure for their fiields from the bottom of the swamp. Thus the tranquill bed of these plants is disturbed and narrowed, and consequently the depth of the littoral part increases. Accordingly, the Typha-zone had been destroyed at many places. In the above places, we can see only two littoral zones :-a loose association of Zizania and a Phragmites-zone.

1) 1.c. p. 6 . 
Luckily the Typha-zone, as well as other littoral zones in the eastern part of the swamp, is protected from the human interference on account of its public hunting place of water fowls. Hence here these zones have most perfectly been preserved

\section{Geographical Distribution.}

In this chapter, an attempt will be made to show the affinity between the plants of the swamp and those of other countries. The total number of phanerogams found in the swamp is 47 species and 8 varieties. The following table will show in percentage the ratio of the number of elements of various countries contained in the present flora, to the total number of it. The only plant endemic to the swamp is potamogeton lucens var. teganumensis.

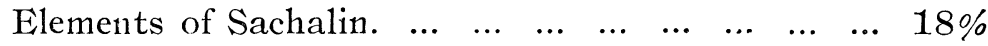

$\begin{array}{llllllllll}\text { Siberia.... } & \ldots & \ldots & \ldots & \ldots & \ldots & \ldots & \ldots & \ldots & 31 \%\end{array}$

$\begin{array}{llllllllllll}\text { Yezo. } & \ldots & \ldots & \ldots & \ldots & \ldots & \ldots & \ldots & \ldots & \ldots & 42 \%\end{array}$

$\begin{array}{lllllllll}\text { Manchuria.... } & \ldots & \ldots & \ldots & \ldots & \ldots & \ldots & \ldots & 60 \%\end{array}$

$\begin{array}{lllllllll}\text { China proper. } & \ldots & \ldots & \ldots & \ldots & \ldots & \ldots & \ldots & 67 \%\end{array}$

$\begin{array}{lllllll}\text { Kiusiu \& Loochoo. } & \ldots & \ldots & \ldots & \ldots & \ldots & 67 \%\end{array}$

$\begin{array}{llllllllll}\text { Formosa. } & \ldots & \ldots & \ldots & \ldots & \ldots & \ldots & \ldots & \ldots & 51 \%\end{array}$

$\begin{array}{lllllllll}\text { British India. } & \ldots & \ldots & \ldots & \ldots & \ldots & \ldots & \ldots & 47 \%\end{array}$

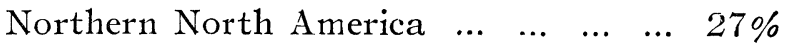

$\begin{array}{llllllllll}\text { Germany. } & \ldots & \ldots & \ldots & \ldots & \ldots & \ldots & \ldots & \ldots & 31 \%\end{array}$

Evidently, this calculation is not accurate, but at large it is sufficient to show the degree of their affinity. Therefore, we may draw a conclusion that the flora of the swamp has the nearest alliance with that of China proper or Manchuria, and agrees with the floras of tropical lands, rather than with those of cold regions. The former relation may be explained by the general assumption that the Japanese flora had originated from that of Asiatic Continent. ${ }^{1)} \quad$ As to the latter it appears

1) Grisebach: Die Vegetation der Erde, Bd. I. p. 489.

ENGLER: Versuch einer Entwickelungsgeschichte der extratropischen Florengebiete, p. 38 . 
to be a principal cause, that a cold climate, as in the case of the higher portion of a mountain, ${ }^{1)}$ is very unprofitable to the water plants.

As we see in the above table, the flora of the swamp has generally a great resemblance to the floras of the distant regions, as aquatic and marsh plants are, in most cases, cosmopolitan. It is partly because of conditions of fresh water which are nearly uniform throughout the world, and parthy because of water fowls which play an important rôle of the distritution of water plants. ${ }^{2)}$

Especially, Phragmites communis is found everywhere in the world, so that reed-swamps may occur also everywhere through the world.

Here I must express my sincere thanks to the most distinguished systematist $\mathrm{Mr}$. T. Makino who had thoroughly identified all the above named plants of the swamp for me, and made a new variety of Potamogeton ( $P$. lucens L., var. teganumensis MaK.)

\section{Conclusion and Summary.}

1. Teganuma (numa $=\mathrm{swamp}$ ) is one of the relics of the Tone, and now half drained, so that its basin is very rich in aquatic plants") and makes an appearance of "Unterseeische Wälder."

2. The swamp is a kind of "Weiher" (Etangs) $)^{5)}$ limnologically. Therefore, it has only the inhabitants ${ }^{6)}$ of the littoral region (Uferbank) of deep lakes, and accordingly there never occurs such a pure association as Chara, Nitella and Cladophora, which all belong to the deeper basin more than two meters.

1) Schenck: Die Biologie der Wassergewächse, 18\&6, p. 157.

2) Forel: Allgemeine Limnologie, p. 213. 1901.

SchencK: l. c. p. 133.

3) Coules: : 1. c. p. 154.

4) Foreis: l. c. p. 182.

5) Ditto, p. 4 and 44.

6) Correspond to tho of the zone of "Weiss" in "Würmsee," Brand: 1.c. p. 4 . 
3. Helophytes round submerged hydrophytes are arranged clearly in four zones. As the ecological factors of this arrangement were considered :-
a. bathometric factor.
b. hydrodynamic factor
c. Edaphic factor
d. human interference.

4. The vegetation of the eastern part of the swamp has an appearance of a marsh (Sumpf), and its plants, both in species and individuals, are the richest of all.

5. The flora of the swamp has the nearest alliance with that of the Asiatic Continent, and has a closer affinity to the floras of southern lands than to those of northern lands.

6. The aquatic and marsh plants which I mentioned in the present report are 49 species and 9 varieties. The numerical relation of these two groups is as follows :-

$$
\begin{array}{rr}
\text { Hydrophytes }=29 & \\
\text { submerged............... } & 16 \\
\text { swimming............... } & 8 \\
\text { floating.................. } & 5 \\
\hline & 29
\end{array}
$$$$
\text { Helophytes }=29
$$

Namely, the ratio of the number of hydrophytes and helo. phytes is 1. As the helophyte increases hand in hand with the age of a lake, the ratio in young lakes must be larger than one.

From this point of view, Tega-swamp which is originated from the course of the river, resembles a lake of old ages. But the time must be long, before it becomes entirely marshy.

Oct. 1910.

Botanical Institute, Imp. Univ., Tokyo. 